\title{
Investigations of Kantian Cosmopolitanism: Evolution of the Species, Sovereignty and Hospitality
}

\author{
Carlos Enrique Ruiz Ferreira \\ PhD Professor. State University of Paraiba. João Pessoa, PB. Brasil. \\ E-mail: cruiz@usp.br, https://orcid.org/0000-0001-9722-2563
}

\section{INTRODUCTION}

Kant's political philosophy writings undeniably consist of important references and historical-philosophical frameworks for international relations and international law. Studying and reflecting upon them continues to hold a high degree of academic relevance, as demonstrated by publications and research projects dedicated to the subject in the area. Kant inaugurates and/or foreshadows a new paradigm within international relations, in which peace and cosmopolitanism acquire epistemological centrality. The object of this article is, again, to investigate this Kantian canon, which is especially represented by five works:

- Idea for a Universal History with a Cosmopolitan Purpose (1784);

- Groundwork of the Metaphysics of Morals (1785);

- Perpetual Peace: A Philosophical Sketch (1793);

- The Metaphysics of Morals (1797);

- Anthropology From a Pragmatic Point of View $(1878)^{1}$

Our approach will not be to reconstruct or realize a reading of cosmopolitanism and Kant's "perpetual peace" project. Yet, we do seek to illuminate three significant founding questions of Kantian political thinking which are directly related to cosmopolitanism and have re-

\footnotetext{
"This article is the result of a postdoctoral research project entitled "Derrida and ethics: hospitality and international relations", conducted at the Department of Philosophy of the University of São Paulo (USP) and funded by the São Paulo Research Foundation (Fapesp) (process no. 2014/21421-7). I am particularly grateful to Professor Olgária Matos for her supervision and to the peer reviewers of DADOS - Revista de Ciências Sociais, who have contributed enormously to the final result.
}

DADOS, Rio de Janeiro, vol.63(2):e20180200, 2020.

http:/ /dx.doi.org/10.1590/001152582020205 
ceived relatively scant attention in international relations and political science studies - such as in the case of the idea of the evolution of the human species as a part or result of nature. Also, these questions ensue significant contemporary implications, challenges and practices - such as in the case of the intersection between sovereignty and hospitality on one side and highly topical issues as migration, citizenship, and nationality on the other.

Each of these issues retains its specificities, although they all are inscribed under the grand liberal chapter of political ideas. In the case of the discussion about "the evolution of the human species", our main aim is to present and reflect upon the philosopher's understanding of what cosmopolitanism and/or the cosmopolitan constitution are, and how they result, in a certain sense, from nature, the natural purpose, and in particular from "unsociable sociability". In what concerns international relations, we adduce a metaphysical connotation according to which evolution and progress are understood as given by nature and/or providence.

With regard to issue of cosmopolitanism versus sovereignty, further explored in specialized literature, the proposal consists of revising and engendering inflections about the interpretive possibilities of this debate by presenting two analytical perspectives. On the one hand, the perspective of those who characterize Kant as an author who adheres to and defends sovereignty. This is based on his considerations about the decision-making process in international scale and the irrevocability of territorial integrity. On the other hand, there is an interpretive line which insinuates a feasible inflection of Kantian thought with regard to the clausula petrea, summa potestas superiorem non recognoscens. This derives especially from the innovative proposal of cosmopolitan law (beyond ius gentium or international law).

Hospitality, our third issue, constitutes the most concrete basis for Kantian cosmopolitanism. In the epigraph for the "Third definitive article" of Perpetual Peace, the philosopher from Königsberg affirms that "cosmopolitan law should be limited to the conditions of universal hospitality" (Kant, 2004a:137). The centrality of hospitality for Kant invokes highly relevant ethical and juridical parameters not only from a hermeneutic point of view, but also regarding international relations and its contemporary dilemmas. Introducing the issue of hospitality enables new comprehensions and discussions 
about the relation between hospitality, the nation and the world - or with cosmos and/or planet Earth - and, thus, with national identities and the notion of foreigner. Our approach to hospitality will discuss the juridical dimension, expressed in Perpetual Peace and highlighted by commentators, but also attempt an original interpretation by incorporating the ethical dimension contained in Groundwork of the Metaphysics of Morals.

As for the organization of the article, before discussing the three aforementioned issues, we make a very brief yet relevant introduction to some historical specificities which surely influenced the philosopher's thought, but are rarely mentioned.

\section{MOMENTS, CONTEXTS}

Interpreters of Perpetual Peace frequently underline that it was directly influenced by the Peace of Basel, which would halt hostilities between Revolutionary France, Prussia and Spain. Yet, three other historic specificities are equally significant for understanding Kantian writings. In first place comes the importance of considering the intellectual impact of social relations established with the conquest of the New World on Europe. This historic circumstance sparked a series of theoretical works approaching so-called ius gentium. Broadly speaking, these discussions revolved around juridical "justifications" for the conquest of the "new" territorial space and the "new peoples" - the Native Americans. Francisco de Vitoria, considered by many the father of international law, acquired notoriety for conceiving the principles of ius peregrinandi, ius migrandi and ius communicationis, among others, which were actually elevated to the category of rights. As their names suggest, they imply a relation between the "I" and the "other" - more specifically, bearing relation to the contact between peoples from an international juridical perspective (Vitoria, 2016). Nonetheless, it is known that the rights of Vitoria authorized the "blessed conquest": exploitative trade unified with catechism.

As it turns out, the emergence of the "other" and the "savage" - either "good" or "evil" - or the native "Americans" provoked Europeans' sensitivity towards seeking disparate ways to understand and explain the "other", the "other-self" relation and, on certain occasions, the "we" as human beings. This issue gains evident relevance in relation to the construction of the idea of the "world". According to Schmitt (2002), 
this was the moment when "the first global lines" appeared, which - relying on Christian philosophy and culture - made ius gentium emerge, but also enabled and prompted discussions about cosmopolitanism and hospitality/migrations - both central issues for Kant.

Another historic phenomenon which draws our consideration are religious wars. In every circumstance, they contributed to fueling the most important political revolutions from a "modern" perspective. These wars largely engendered sovereign territorial contours, and concomitantly, absolutist states, leading to the primacy of the raison d'état over Christian and religious morals (Anderson, 2005; Kissinger, 1995). The so-called Westphalian sovereign paradigm is a heritage from religious wars. In this regard, as we shall see, the idea of "sovereignty" crystallized as a concept and political fact, became one more cognitive paradigm for Kant's thought about the social and political world, either within the domestic or the international realm.

Lastly, it is pertinent to consider the French Revolution, even though this subject might have been widely discussed. Endless factor have amounted to the Revolution - our most profound genetic-politicalcultural-baggage ${ }^{2}$. Our discussion focuses on three especially relevant factors: the growing appreciation of free will - in contrast with religious doctrine -; the inversion of sovereignty ownership, from the king to the nation, and; human rights, understood not merely as a right of the citizen, but also as "rights of man" - referring to humankind. These ideas resonate Kant not only with regard to the triumph of reason at the cost of religion and faith, but also to the epistemological centrality conferred upon individuals and their "natural" or "human" rights, which, thereafter, would merge with the idea of a global or cosmopolitan society.

In Kant's works, all of these factors do contemplate political facts and ideas of significant implications, which influenced and structured the politico-philosophical thinking of the $18^{\text {th }}$ and $19^{\text {th }}$ centuries.

\section{KANTIAN COSMOPOLITANISM}

The character of the species, in accordance with that which notoriously results from the experiences of all times and all peoples, is this: The human race taken collectively (as the entire human 
species) is a great number of people living successively and simultaneously. They cannot be without peaceful co-existence, and yet they cannot avoid continuous disagreement with one another.

Consequently, they feel destined by nature to develop, through mutual compulsion and laws written by them, into a coalition, which is constantly threatened by dissension. Yet, generally progressing toward a universal civil society (cosmopolitanism). Immanuel Kant (2004a:278; Emphasis of the original)

a) The nature of the evolution of the human species

fata volentem ducunt noletem trahunt (destiny guides what obeys it, and drags who resists it)

Immanuel Kant (2004c:101)

It is difficult to understand Kantian cosmopolitanism without considering the notion of the evolution of the human species. This notion, widely characteristic of his work, constitutes a cornerstone for the construction of the political edifice of Perpetual Peace and cosmopolitanism. In other words, it is confirmed as a cognitive presumption for the construction of peace and cosmopolitan law - a statement especially corroborated by the book Idea for a Universal History With a Cosmopolitan Purpose.

Kant's first proposition affirms that "all natural capacities of a creature are destined to evolve completely to their natural end". He further explains that "an organ that is of no use, an arrangement that does not achieve its purpose, are contradictions in the teleological theory of nature" (Kant, 2003a:5). This perspective characterizes nature with inherent reason and internal order, which obeys universal laws. This implies that nature has as a purpose to fulfill an objective, a design connected to the order of things. For example, he states that "nature does nothing superfluous, and is, in the use of means for her purposes, not squandering" (Ibid.:6). A logical connection can thereby be identified between the means and the ends of nature - which the philosopher similarly refers to as providence ${ }^{3}$.

Kant's works therefore already include notions of "evolution" and "progress", which would provide the nucleus and foundations for large parts of political liberalism within the realm of the history of political 
ideas. His first observations about them are part of his reflections in fields such as natural life or natural sciences. Later, his studies on international politics - of main interest to us - begin to include them.

Kant argues that the "evolution" of man can only be observed in the "human species" and not in isolated individuals. He therefore defends that evolution occurs only in the species (collectively) and not necessarily in individuals per se: "In man those natural capacities which are directed to the use of his reason are to be fully developed only in the race, not in the individual" (Kant, 2004a:23). This process thus can only be noted and evidenced in macro-history - or the universal history.

The origin and justification of such evolution lies in the notion of "unsociable sociability" - a term suggesting an imminently antinomic reflection about human nature. By appropriating this language, Kant simply affirms that man cannot "stand" the other. Yet, neither can he "do without" him. Thereby he reveals one of man's main afflictions, thus stated: "By antagonism, I here mean the unsocial sociability of mankind - that is, the combination in them of an impulse to enter into society, with a thorough spirit of opposition which constantly threatens to break up this society" (Kant, 2003a:8) ${ }^{4}$. Brought to its logical extreme, this is about a kind of human drama which spurs a behavior characteristic of double personalities with antagonistic character: isolate oneself and, simultaneously, associate oneself; reject and want, reject and need.

In summary, the philosopher concludes that the human species evolves in accordance with the designs of nature, as this evolution has the antagonism between men as its origin. The contradiction in movement - interactions of forces - is what often brings humanity to the brink of war. It is through this "bloody path of wars" that we can reach peace, in this "profound, and perhaps prophetic vision of Kant" (Aron, 2002:66). It is thus unsociable sociability that enables progress. And this progress becomes politically evident: first in the civil peace, second in the constitution of a state and, subsequently, in the perpetual peace, agreed upon by all states. 
The thesis about the evolution of the human species - which implies we are advancing with the passing of time - thereby becomes a foundation for Kantian political thinking which has direct implications for cosmopolitanism and the perpetual peace. It is thus worth the effort to further elaborate on the bases that explain such evolution.

For Allan Wood (2006), the thesis about the evolution of the human species - or, as the author states, "Kantian philosophical history" gains meaning through a more theoretical than empirical exercise to understand the course of history. This is also, with all of its nuances, Otfried Höffe's (2005a) interpretation. Hence, the idea of evolution as engendered by nature and by unsociable sociability is in its essence not empirically proven.

This interpretation makes sense, although the philosopher bases his argument on the existence of "universal natural laws" (Kant, 2003a:3). In this regard, the preface and the ninth proposition of Universal History (Kant, 2003b) are important. The latter includes the philosopher's reconstruction of a history of human political evolution, comprising Greeks, Romans and their influence on barbarians and other peoples etc. In a concluding note, he states that "we will discover a regular path of perfection of political constitution (Staatverfassung) in our part of the world" (Kant, 2003a:20-21).

Kant mentions some empirically verifiable historic factors, but, according to Wood, only highlighted in order to find some meaning over the course of time. This meaning, an "idea or rational concept a priori" $^{5}$ (Wood, 2006:245), stands out in the explanatory elaboration. In theory, the concept thereby gains density when history displays a meaning of "progress towards freedom" (Höffe, 2005a:274). Once again, Enlightenment prevails, leaving its legacy to the several lines of liberalism.

Another historic fact marking Kant's understanding of the political progress of the human species is the advent of the republic. The evolution of the human species at first finds its political realization in the founding of the civil state as a practical result of evolution. A passage in Kant's text "On the common saying: this may be true in theory but it does not apply in practice" highlights three a priori principles of the civil state - understood as a juridical situation -, which will be 
reassessed in the "First definitive article" of Perpetual Peace. These principles not only define a civil state established by contract, but also imply its republican character ${ }^{6}$.

The realization of a republican constitution requires first of all the existence and effective employment of "principles of freedom of the members of a society (as men)". Second, it demands "principles of dependence of all in relation to a single common legislation (as subjects)". Third and finally comes the "law of equality of the same (citizens)" (Kant, 2004a:127-128). Achieving a civil state or a republican constitution results from man's acquiring certain maturity, thus characterizing him according to an evolutionary "pattern" typical of the Enlightenment. This pattern should eventually reach a higher level, at which the civil state encompasses the world, the international and the Cosmo polis. In Kant's words: the civil state appears to become a "cosmopolitan constitution"7.

As we move beyond the discussion between theory and experience regarding the notions of evolution and progress, and as we approach the proposition of free will, a pertinent question arises: is Kantian politics not derived from the designs of nature and unsociable sociability? If the answer were affirmative, what would be man's role as a fundamental agent of contracts, reason and law, materialized in the positive image of civil peace and the state?

In this case, we completely agree with Wood (2006), Höffe (2005a), and Klein (2014), highlighting the coexistence of both perspectives. On the one hand, the Kantian edifice is especially derived from a theoretical construct. On the other hand, a normative perspective or even eagerness remains with regard to events and to man's role of men in the search for freedom and justice. Besides the comprehension that we naturally move towards justice and perpetual peace, Kant displays a moral proposition of duty, which defines human beings as participants in the course of history. For Wood, these are two interdependent perspectives or "theses". Hence, the Kantian message - albeit often difficult to understand - suggests that, although nature/providence is accountable for promoting perpetual peace through laws and devices such as unsociable sociability -, human beings should nonetheless act and promote the politics of peace. In the words of Wood: a theoretical and a practical or moral thesis (Wood, 2006:254-255). 
In other - and in our - words, cosmopolitanism would at the same time be a common destiny of humanity and a moral duty of the individuals in their actions in society.

\section{b) Cosmopolitanism and sovereignty, beyond Westphalia?}

A timely international relations issue which has inspired philosophers and thinkers relates to whether cosmopolitanism, if brought to its final consequences, would supersede the paradigm of territorial sovereignty. Contemporary international relations lead us to wonder whether cosmopolitanism already supersedes sovereignty in some cases.

With respect to the legal environment, it is plausible to consider that the Charter of the United Nations comprises a dual focus. If, on the one hand, the Charter elaborates on and defends the principle of sovereign equality and non-interference (Chapter 1, Article 2), on the other hand, it applies a more flexible approach to the paradigm of territorial inviolability in Chapter VII. Article 42 in particular stipulates the "imposition of peace" when all pacific means and economic sanctions have been exhausted ${ }^{8}$. From a practical point of view, peace operations numerically and politically significant in the organization - in a certain degree bear witness to the prevalence of "human rights" or "human interests" to the detriment of the fundamental clause about intervention in internal affairs of each sovereign state - although the clause is permanently untouchable for some select states, amongst which the permanent members of the Security Council ${ }^{9}$.

The ideas of a politically unitary world, a world government, a world republic, and a cosmopolitan constitution - all of which enable multiple interpretations - inspire - by recovering an ethical spirit - and alarm - by promoting a significant rupture. How is it, however, that this issue appears in Kant? Does it appear in the form of a dichotomy - or possibly even an antinomy - or in the form of coexistence and harmony?

At first sight, there is certain consensus about the issue in specialized literature about Kant's cosmopolitanism: the ius cosmopoliticum innovated and renewed the philosophy of law, thereby inaugurating a "third type of law within the Theory of Law" (Habermas, 1997; Chernilo, 2007; Kleingeld, 2006; Nour, 2003; 2004). If until then juridi- 
cal studies had been divided between state law (ius civitatis) and international law (ius gentium), the philosopher from Königsberg consecrated a third type: cosmopolitan law (ius cosmopoliticum).

It was in Perpetual Peace that the philosopher ascribed centrality to this third type of law, but also exposed the polemic between "cosmopolitan law" and "sovereignty". This polemic would turn out to be highly profitable not only in relation to the philosopher's texts, but above all as an issue connected to a series of reflections about contemporary international relations. One of Kant's few passages about this thematic demonstrates the existence and distinction of the three types of law ${ }^{10}$ and portrays the aforementioned polemic:

All juridical constitutions, with regard to the people who find themselves in them, are:

1) A constitution according to the political law (Staatsbürgerrecht) of men in a people (ius civitatis);

2) According to the law of the people (Volkerrecht) of the states in their reciprocal relations (ius gentium);

3) A constitution according to cosmopolitan law (Weltbürgerrecht), since it is important to consider men and states in their reciprocally influential external relations as citizens of universal humanity (ius cosmopoliticum) (Kant, 2004a:127).

Is it possible to think of cosmopolitan law as conflicting with the practice of the sovereign state? Would thinking of the political man as participant in a "universal state of humanity" and of world-citizen or universal-citizen categories not mean to consider a juridical and political bond spanning beyond the national citizen and national territories? Is this a new cognitive paradigm?

The change materializes in the relation between the collective and the individual, by attributing centrality to the individual. Would the identity of the "new" political individual - the citizen - be more inclined towards "humanity" than towards a national community or the state? This would ensue abolishing - in the most radical form or transcend - in its mildest form - the particularity of the national and the link between the individual and the state or nation. Thinking of the cosmopolitan citizen nonetheless leads to the question: what political order would follow him? Immediate association leads us to 
believe that the sovereign state in this new order would tend to become at least diminished in force or potency in order to give way to a new potestas-collective.

However, what looks at first like an opposition (sovereignty versus cosmopolitanism) is brought together by Kant into coexistence (in possible harmony). The very beginning of Perpetual Peace includes six preliminary articles for the construction of perpetual peace between states. The "Fifth Definitive Article" defends sovereignty, especially in its internal scope: a defense of what is conventionally called the "principle of non-interference in the internal affairs of sovereign states" in contemporary terms. Kant makes a careful of the sovereign prerogatives in what concerns the control of internal territories.

Yet, considering that his political philosophy works were among the last of his life, and that they were still under elaboration ${ }^{11}$, it would not be too unwary to present the hypothesis that the philosopher thought of the possibility and the need to diminish or loosen sovereignty to the benefit of cosmopolitan law. Maybe the most central passage at the core of the text, which in a very clear manner exemplifies the contradiction between cosmopolitanism and sovereignty, could help us to justify the hypothesis:

According to reason, there is only one way for states involved in reciprocal relations with one another to leave the lawless condition, which involves nothing but war: as individual human beings, they give up their savage (lawless) freedom, consent to coercive public laws and form an (always increasing) state of nations (civitas gentium) which would finally encompass all nations of the earth. If they, however, according to their idea of the right of nations, do not at all want this, thus rejecting in hipothesi what is in thesi correct; then (if all is not to be lost) in place of the positive idea of a world republic, only the negative surrogate of a permanent and always-expanding league that averts war endures and is able to hold back the stream of hostile and unfair inclinations, under constant danger of breaking out (Furor impius intus - fremit horridus ore cruento. Virgil.) (Kant, 2004a:136).

This passage might be the most polemic. Kant categorically affirms that, in order to leave the state of nature, states have to submit to certain coercive public laws. On the other hand, the philosopher an- 
ticipates the inviability of a world republic: for, if the positive cannot be realized (the world republic), then the negative substitute must be applied: the federation of peace.

Interpreters are divided. Most sustain that Kant does not oppose sovereignty as it was then configured, neither does he propose its relativization given cosmopolitan law (Habermas, 1997; Arroyo, 1997; Nour, 2004; Wood, 2006). As summarized by Habermas:

The so-called "cosmopolitan order" should be differentiated from the interstate juridical order, namely that: states must not submit to public laws of a superior power like individual citizens do, but rather maintain their independence (Habermas, 1997:54).

In the same interpretive vein, Soraya Nour emphasizes the normative difference expressed by Kant in the words reunion (Zusammentretung) and union (Verbindung) (Nour, 2004:52). The reunion, as the philosopher states, can be dissolved at every moment, leading to the idea that sovereignty holds the "last word". On the other hand, the union leads to the idea of assembling parts, as they would lose their sovereignty. Typical examples of the latter include the founding of the United States of America and even the creation of Germany in 1870. Hence, Kant opts for the federation of states as a reunion, and not as a union ${ }^{12}$.

Kant therefore had not proposed a world republic: his solution is rather a federation of states, thus maintaining their sovereignty. In line with Habermas (1997) and Arroyo (1997) we presume that the historic conditions in which the philosopher was immersed did not enable him to produce one more conceptual rupture; sovereignty was still a dogma which was difficult to question and/or supersede.

Another perspective derives from Höffe's analysis, which moves Kant towards a proposal that overcomes sovereignty. The author displays a certain prevalence of the "positive idea" with regard to the "world republic": "In the model for interstate peace enforcement, there should be in fact a World Republic for the league of global peace, in conformity with the "positive idea'" (Höffe, 2005b:303). And he completes: "using the partially 'realist' and partially moral-juridical argument [...] Kant was satisfied with the 'negative substitute', thereby preferring another solution: a league of peoples" (Höffe, 2005b:303). 
The possibility of a new Kantian international order, in which sovereignties would become diminished - and in which the maxim summa potestas superiorem non recognoscens would be questioned - is emphasized in a text prior to Perpetual Peace. In Theory and Practice, from 1793, the philosopher, worried about peace, prescribes that "no other remedy is possible except for [...] the law of the peoples, based on public laws supported by power, to which the state should submit [...]" (Kant, 2004b:101). This passage suggests agreement with Georg Cavallar's proposal for the existence of an idea or suggestion of the need for a coactive power in the international realm (Cavallar, 1992:202).

Seyla Benhabib in her turn provides an equally interesting interpretation. Based on a reading of Perpetual Peace, the author indicates a sort of movement in Kantian thought towards a postWestphalian world. Once again, the thesis about Kant's consideration of a world beyond sovereignty gains strength. Benhabib defends that the Kantian essay "signaled a watershed between two conceptions of sovereignty and paved the way for the transition from the first to the second" (Benhabib, 2006:23). She denominates these two conceptions as "Westphalian sovereignty" and "liberal international sovereignty", but she is cautious in considering Kant as a supporter of the second alternative-according to which sovereignty "no longer means ultimate and arbitrary authority over a circumscribed territory" (Benhabib, 2006:24). We endorse the author's prudency, which seems appropriate in terms of the linguistic devises applied: for her, Kant does not found the thinking or defends the idea of a post-Westphalian world. He rather, in her perspective, "laid the foundations for a post-Westphalian legal order" (Benhabib, 2006:23).

The first conclusion to be drawn some this discussion corroborates the statement about Kant's modification of his concepts and formulations about cosmopolitanism and sovereignty over the years (Kleingeld, 2013; Byrd and Hruschka, 2010; Cavallar, 1992; 2002; Hurrel, 1990). The prevalence of more cosmopolitan concepts close to a world republic and/or a binding international law and/or a cosmopolitan constitution are accentuated in his early writings, such as Idea for a Universal History with a Cosmopolitan Purpose and Theory and Practice. The more "sovereignist" affirmations, so to speak, crystallize in later works, such as Perpetual Peace, The Metaphysics of Morals and Anthropology (Hurrel, 1990). This issue becomes clearer by considering the terms used by the philosopher. This cosmopolitanism - or these cosmopolitanisms 
- appears in the terms "federation of nations (Foedus Amphictyonum)" in Universal History; in a "cosmopolitan constitution" or a "federation according to the law of the peoples" in Theory and Practice; and as a "federation of peace" (Foedus Pacificum) and/or "federalism attached to the law of the peoples" in Perpetual Peace.

A second conclusion refers to the fact that, in the Höffe's and Benhabib's lines of interpretation, it would not be unwary to consider that Kant at least considered the overcoming of a world exclusively marked by the order of the Westphalian sovereignty. In line with this interpretation, the concept of cosmopolitan law inaugurated by Kant gains prominence, the roots of which stretch beyond civil and international law. In the words of Benhabib, this cosmopolitan law, embedded in the notion of hospitality, can be situated "at the boundaries of polity; it delimits civic space based by regulating relations among members, strangers and communities (Benhabib, 2006:22). Consequently, if cosmopolitan law does not emerge to rearrange (in the radical hypothesis) or to overcome and aggregate (in the milder hypothesis) the law in effect until then - hypotheses of which lead to modifications or ruptures in paradigms and in the status quo - why then not merely reform the law of the peoples (international law)? Why create a new juridical figure for international relations?

\section{c) The flag of hospitality}

In the seminary Hostipitalité (1995-1997), Jacques Derrida considered that the horizon of universal hospitality was determined by Kant (Derrida, 1995-1997) ${ }^{13}$. In his words: “Je dis déterminé par Kant, car celui-ci ne l'a pas inventé, il en a formulé et formalisé la nécessité [...] d'un [...] progrès considérable dans l'histoire de l'humanité".

It is clear that hospitality as a concept or principle was not invented by Kant. Nonetheless, it would not be too risky to claim that Kant reinvented it, or rather invented a new formulation and/or perspective for this concept-practice. His considerable progress meant positioning hospitality as a central, propelling - so to speak - element of the project of peace between states through cosmopolitan law. This is the introduction of hospitality - or the right to hospitality - in the field of modern international relations. Kant thus inaugurates a right to hospitality which should be inscribed upon international juridical corpora and international politics. In this regard, we propose to 
consider Kantian hospitality in a scope which is normative scope, structural for his thought and highly innovative, especially present in Perpetual Peace. For this task, we are assisted by the works of some commentators who discuss this issue.

There is likewise an issue which has not been very commented or discussed by the scholarship on international relations (Covell, 1998; Hinsley, 1980; Hurrel, 1990; Wilkins, 2007) and other areas dedicated to Kantian Perpetual Peace - as well as to the issue of the evolution of the species: the possibility of an ethical hospitality in Kant. Commentators highlight hospitality as a right, mainly - or even exclusively based on Perpetual Peace (Covell, 1998; Benhabib, 2006; Cavallar, 2002; Derrida, 2004; Derrida and Duffourmantelle, 2015) ${ }^{14}$. Therefore, the most significant and unanimous originality found in Kantian works by authors refers exclusively to hospitality as a right. In fact, as we also defend, this originality becomes latent and reveals or incites a new kind of international juridical ordering, including with regard to international relations, as we shall see in the following. Nevertheless, commentators' emphasis on Kantian hospitality as a right deserves some degree of caution.

Although the ethical debate is not the main theme in Perpetual Peace, it consists of a central axis in the philosopher's broader work. We thus take a turn towards a new interpretation in search for the foundations of Kantian hospitality in the ethical realm. The Groundwork of the Metaphysics of Morals and The Metaphysics of Morals - especially its section dedicated to the doctrine of virtue - are particularly significant in this regard. It is clear that hospitality is not object of deep consideration in Kant's late works - in contrast with Perpetual Peace-, but the obligations of virtue and ethics provide us with a possible interpretation in which hospitality comes to the fore. We consider thus both perspectives: of hospitality as ethics and, from a more common point of view, hospitality as law.

\section{HOSPITALITY AS AN ETHICAL OBLIGATION}

For Kant, "ethical obligations involve lax commitments, while legal obligations involve strict commitments" (Kant, 2003b:233). From this comprehension - which does not appear in his earlier writings - we can infer why hospitality is constructed by law and not by ethics in Perpetual Peace. Thus, if his intent was to promote peace (through a "project", as 
the very title of Perpetual Peace indicates), the first interlocutors are states, which in turn interact not on basis of values or ethics, but rather law. In this regard, hospitality by law - or conditional hospitality, as stated Derrida - plays a vital role. Nonetheless, we repeat, it seems viable to think of hospitality as an ethics based on The Metaphysics of Morals.

Kant (2003b:233) assumes that "human beings persist to be free (moral)" and "exist as an end in itself, and not merely as a means for the arbitrary use of this or that will" (Kant, 2007:68; Emphasis of the original). Therefore, ethical issues are not only important, but rather fundamental and constitutive of human beings. Kant states that "morality is the only condition that can make a rational being and end in itself" (Kant, 2007:77).

Hence, ethics and law comply with different statutes. For example, while legal doctrines concern the "formal condition for external freedom", it is up to ethics to produce "materia (an object of free choice), a finality of pure reason", which would imply the human "an obligation to possess" (Kant, 2003b:224-225). Law, on the other hand, would correspond to the strict obligation and condition for external freedom, while ethics would correspond to the lax obligation of internal freedom.

As ethics relate to the "obligations of virtue", law relates to "the obligations of law", in which coercion obviously plays a central role. Law, in this regard, becomes socially and legally mandatory, as it refers directly to the compliance to the necessary conditions for the minimal preservation of social order. Therefore, noncompliance with it leads to public sanction and coercion. Virtue, on the other hand, is "the moral strength of a human being's will in fulfilling his duty, a moral constraint by his own lawgiving reason, insofar as this consists in itself of an authority executing the law" (Kant, 2003b:248; Emphasis of the original). Therefore, ethics corresponds to virtue: the individual's internal (of internal freedom) self-regulated capacity or will. In this case, it means a capacity or an action which is not necessarily subject to the dictates of the instituted or institutional social order. Therefore "ethics does not propose laws for actions (ius does that), but only for the maxims of actions" (Kant, 2003b:232).

As we have stated, although the philosopher does not explicitly treat hospitality in these texts (GMS and MS), we find a maxim among his obligations of virtue that could very well be assimilated to the 
ethical duty of hospitality. It concerns the obligation of the virtue of "the happiness of others", understood "as an end which also constitutes an obligation" (Kant, 2003b:237). This item - "Exposition of the obligations of virtue as lax commitments" - observes that: "the reason why an obligation is beneficial is this: as our self-affection is inseparable from our need to be loved (assisted if need be) by others, we ourselves become an end for others" (Kant, 2003b:237). Hence, for this maxim's success, requires it to be qualified as a universal law, so that, in other words, the happiness of others becomes an end and an obligation (Kant, 2003b:237) ${ }^{15}$.

The happiness of others is therefore an obligation of virtue, because not honoring or effectuating it would not directly affect the social order and the existing right. There would be no legal sanction or coercion for its non-implementation. Nonetheless, if this obligation was realized and practiced, the virtue would be consecrated - a fundamental element for the man of the enlightenment in search of perfection.

It is thus possible to infer the proximity between the maxim of the search for the happiness of others with the imperative of hospitality. Although Kant has not worked specifically on the issue of the reasons for migration, indeed the "right to hospitality" (as the philosopher explains) or the "ethical imperative of hospitality" (as we propose) obviously depends on migration and its conditions. We consider that, migrants' origin or motivations (political or environmental refuge, labour, economy or even tourism) do not change the fact that the act of migrating implies migrants' insecurity. The insecurity of leaving one's familiar home/territory and entering another space (often unknown and with a distinct language). From this perspective, hospitality can be seen as an ethical act to provide newcomers with some security and/or comfort (the bases, to some extent, for happiness).

Furthermore, in another part of The Metaphysics of Morals, the "Doctrine of the Elements of Ethics", the philosopher presents the "obligations towards others" (a part of the ethical division with regard to the distinction of subjects and laws) and emphasizes "love" as the central axis, which is further on sub-divided in benevolence, gratitude, and solidarity. Once again, the issue of benevolence enables a connection with hospitality, as "being benevolent, or rather, promoting the happiness of other human beings in need through one's own means without expecting something in return is the duty of all" (Kant, 2003b:296). The 
idea of hospitality towards migrants becomes invigorated due to their always uncomfortable, insecure, or unstable situation. In this regard, they are in need of help, support and solidarity. In conclusion, his condition demands someone benevolent, as "everyone who finds themselves in need desires to be helped by others" (Kant, 2003b:296).

Therefore, although the philosopher does not exactly elaborate on hospitality, it is possible to infer that hospitality is considered as a part of ethics, an obligation of virtue, in terms of the duty to welcome ones who need shelter and some rest, or who might even have arrived in foreign lands under perfect conditions (economic, travel-related etc.). This "other", often a foreigner, who leaves his home and/ or nation (his domi) for many reasons towards an unknown land - or a land of others (exterior/foreign) - will invariably arrive in a condition which requires help, care and attention. At last, the foreigner and/or migrant needs, demands, requires sheltering, hospitality and benevolence.

This inference is justified with basis in the Groundwork of the Metaphysics of Morals and The Metaphysics of Morals - thus, in the realm of ethics and ethical relations between human beings. More specifically, in the relation between one individual and another. It concerns therefore another terrain and another locus than the ones of law or the state - or the law of the state. It is situated among moral maxims which preserve or suggest certain patterns of obligations between people. In this sense, our discussion confers epistemological centrality upon the individual and not the state, suggesting the emergence of an ethical Kantian hospitality beyond the hospitality of law ${ }^{16}$. This focus, for example, can be detected within the analyses of some international relations classics, such as Martin Wight (1987; 2002) and Hedley Bull (1976; 2002), in their readings of Kant. Bull synthesizes this comprehension by stating: "the dominant theme of international relations, on the Kantian view, is only apparently the relationship among states, and is really the relationship among all men in the community of mankind" (Bull, 2002:25) ${ }^{17}$.

This possible interpretation of Kantian ethical hospitality therefore does not regard international law or relations between states - as in Perpetual Peace - but rather the ethical realm and the interactions between human beings. 


\section{HOSPITALITY AS LAW}

The "Third Definitive Article" for Perpetual Peace begins with: "We here speak [...] not of philanthropy, but of law, and hospitality means the right of a stranger not to be treated as an enemy when he arrives in the land of other" (Kant, 2004a:137). Maybe this sentence is the reason why little attention has been given to the issue of hospitality in the field of ethics, as we defend. Nevertheless, the innovation of hospitality in the field of law and international relations is a well-known fact. We must remember that Kant, in this project-text, presents a normative argumentation. His focus is to reach a specific objective: peace among states. Once dealing with states, we must also deal with law, such the centrality of the legal subject in writing.

Yet, taking a critical distance to the "new" perspective concerning ethical hospitality in Kant and considering more usual and consensual discussions, Perpetual Peace emphasizes the recognition of hospitality as law and not as virtue. Hospitality, therefore, is not a friendly and voluntary act following the local or national citizen's goodness or benevolence towards foreigners, but becomes structured as law and concerns state actors - and not individuals. From this perspective, the right to hospitality can be seen as a human right which should be respected by the laws of states (Benhabib, 2007).

One of the main foundations for universal hospitality resides in the idea that "originally, no one is more entitled than others to be in a specific place on Earth" (Kant, 2004a:137). Hence, if we take this line of thinking to its logical extreme, the right to hospitality might represent a rupture from the traditional way of understanding and respecting certain sovereign prerogatives. This right means that it is not legitimate for a country to deport people when they first arrive. And this does not only concern political refugees, the politically persecuted etc. - or rather: it does not only concern the right to asylum and the principle of non-refoulement. It concerns the fact that all human beings, that all immigrants, have the right to go and to be in another country.

Kant obviously did not mean that "being" in another country ensues a "right of residence", but merely a "right to visit". The right of residence, which implies citizenship rights, would be the object of other 
particular treaties. Likewise, the right to hospitality as a right to visit would be restricted by the guest's obligations to good behavior, assuming non-violent and peaceful attitude.

Nevertheless, despite these limitations - which among other things lead Derrida to consider Kantian hospitality as "conditional" (within the law of the state and therefore, limited) -, we find in the cosmopolitan law of Kantian hospitality a comprehension of a world in which frontiers should be flexible and open, enabling the free circulation of people. But would this not put in check the dilemma of the states' sovereignty over the land? The German philosopher does not - as the cynicals do - deny the nation, nationality and the political meaning of clearly defined territorial spaces as a function of the national and the community. On the contrary: nihil obstat he resonates the cynicals for considering and/or thinking in terms of supranationality as a sort of community of humanity. After all, the idea of the universality of rights emerges and prevails in this scenario; human rights.

This supranationality and/or universality is also evident in Kant's justification for the right of visit. This right "helps all men to present themselves to society, in virtue of the right to common property of the surface of the Earth" (Kant, 2004a:137). With regard to this issue, a preliminary parenthesis is necessary.

We consider both translations to Portuguese (by Portuguese publisher Edições 70, on p. 137, and Brazilian Perspectiva, on p. 51) to be incorrect in this particular respect. The correct translation is the right to the "common possession of the surface of the Earth" (gemeinschaftichen Besitzes der Oberflache der Erde). There is a substantial difference. For Kant, possession consists - as described in Hugo Grotius's De jure belli ac pacis - of an "originary participation of all in the possession of the Earth" (Höffe, 2005a:248). This idea does not have any empirical basis, but rather a conceptual one, and it serves as a reminder and landmark for the fact that private law is directly originated from a juridical act, but its material basis is simply bequeathed, donated to men (Höffe, 2005a:249) ${ }^{18}$.

Once again, this supranationality, when analyzed from a theoreticalconceptual perspective as the "law of the surface [...] which belongs to the human species" (Kant, 2004a:137), is consecrated as a project of Perpetual Peace based on a right, with a hospitality interface in rela- 
tion both to men and states. This would result in a world in which people do not need passports but free circulation nonetheless is assured. As a consequence of conditional hospitality and these "pacific relations", which would eventually become legal and public, we would move increasingly closer, as a "human species", "to a cosmopolitan constitution" (Kant, 2004a:137-138).

Last but not least, it is relevant to consider Jeremy Waldron's (2000; 2006) interpretation according to which Kantian hospitality is not restricted to a state-centric dimension. The author underlines that it is based on the conceptual defense of contact and exchange between peoples. This principle thus nurtures the right to hospitality. Or rather, in the contact between peoples, in relation to which we might even consider premodern states, for example, rises the aspect of commercium.

With regard to the commercial realm, Michael Doyle (2006:229) emphasizes that the cosmopolitan right to hospitality is related to the principle of free trade as defined by liberalism. Garreth Brown (2010: 310), in an analysis similar to Waldron's, claims that hospitality could be understood as a normative necessity for materializing the ethical condition of intersubjective contact and communication ${ }^{19}$. Waldron in turn introduces the theme of culture by referring to the importance of contact between peoples. Again, this author calls attention to a double-sided strand of cosmopolitanism and hospitality: one which is sustained and materialized by rules and order, and another which resides in culture and moral sentiments (Waldron, 2006:91). Trade interactions between peoples would consist of a commercial relation in a strict sense, but they would also foster cosmopolitanism through the contact between different cultures, values and modes of life.

Although these authors do not comment on the issue of language, our considerations do relate to it. This commercium, beside the exchange of products, would also lead to an "exchange" in the linguistic realm. Would it be too daring to imagine the creation of a new language - the language of hospitality, which could involve spoken and body language, for example - at least there would be linguistic interchange and very probably processes of mutual learning, creating and strengthening cosmopolitanism. 


\section{FINAL CONSIDERATIONS}

The great polemic ensued by Kant's cosmopolitanism and Perpetual Peace project either in theory or in international relations concerns the possibility of diminishing the power of sovereignty and thus rupturing with the classical understanding of international relations based on the Westphalian dogmatic. Even if we adopt the understanding that Kant did not annul - neither intended to annul - the classic power and prerogatives of Westphalian sovereignty, we cannot overlook issues in his work which enable some reflection in this regard. In this article, we have sought to outline a perspective of potential inquiries and interpretations, contributing to debates in the area.

Since Kant's political writings are among his last, and were probably still under elaboration - as mentioned, they include different approaches to this issue - it is up to us to illuminate and explore these discussions, which are very valuable - or even increasingly valuable - for the contemporary world. The dilemma between sovereignty and human rights and/or sovereignty and cosmopolitanism represents first of all a domestic issue: national commissions for truth and/or memory have been recently created to revisit periods of military dictatorships in Latin America. Also, this dilemma concerns international relations in cases such as when the United Nations authorizes peace operations with the prerogative of the use of force. The highly polemic Responsibility to Protect report, issued by the International Commission on Intervention and State Sovereignty (2001), introduces the concept of responsible sovereignty, which highlights the timeliness of this issue for international studies.

Furthermore, our discussion about hospitality aims at bringing ethics to light as a central point, despite more consensual opinions. It is clearly an interpretation still under construction, but we believe it deserves scrutiny. In addition to recovering Kant's writings about ethics to support this analysis, we also stress the need to appreciate some classic international relations works, such as M. Wight and $\mathrm{H}$. Bull, who remind us that, after all, the Kant's core concern or object is not about states themselves, but rather individuals and their actions, which states and international relations - hopefully peaceful - are both a byproduct of and an instrument to. 
As for hospitality, this issue has become urgent in domestic and international realities. As we write in this article, some 247 million people live in a country different from that in which they were born, which represents 3,4\% of the global population (World Bank, 2016:V). The issue of refugees and asylum represents one of today's greatest dramas. At stake is the right to visit in relation to the right of residency - a question inherited from Kant of which the difficulties of the Syrian population on their way to Europe is not a small reminder. Gestures of conditional and unconditional hospitality, rooted in law and in ethical principles, were made by few, such as German chancellor Angela Merkel, who announced that "the fundamental right to asylum from political persecution does not know any limits" in an interview to the Rheinische Post on $11^{\text {th }}$ September 2015. Nonetheless, conservative resistance to her claims about "unconditionality" (to those who flee from situations of serious human rights violations) were so powerful that they eventually made her retreat. Fortunately, specific migration departments in a range of international agencies have multiplied, as have NGOs and civil society associations working on the issue and with migrants.

Hence, many of the questions posed by the philosopher from Königsberg, such as the Global Republic, the Federation for Peace, the right to hospitality and the right to visit, constitute ideas and proposals of extreme contemporary pertinence. Fortunately, this research about Kant's political philosophy writings, reinforces the understanding of the need for new cognitive assumptions for new ways of global organization. In conclusion, reading and discussing Kant is not only intellectually profitable, but, after more than two hundred years, it also enables fundamental discussions about contemporary challenges that intertwine philosophy, politics, and international relations.

(Received for publication August 20, 2018)

(Resubmitted January 18, 2019)

(Approved for publication April 6, 2019)

\section{NOTES}

1. The citations of Kant throughout this text use abbreviations in accordance with Akademie-Ausgabe, namely:

Anth - Anthropology From a Pragmatic Point of View

GMS - Groundwork of The Metaphysics of Morals

IaG - Idea for a Universal History With a Cosmopolitan Purpose

MS - The Metaphysics of Morals 
TP - With Regards to The Expression: "This Might Be Correct In Theory, But Not in Practice" ZeF - Perpetual Peace: a Philosophical Project

2. "The revolutionary consciousness of 1789 is the site of origin of a mentality marked by a new consciousness of time, a new concept of political practice and a new representation of what might be considered as legitimation." (Habermas, 1990:100)

3. This concept follows Montesquieu's tradition: "Laws are, in their most widely accepted sense, the necessary relations that derive from the nature of things. In this regard, all beings have their laws: Divinity has its laws, [...] the animals have their laws; man has his laws [...] therefore there exists a Primitive Reason, and the laws are the necessary relations that exist between that, and the different beings, and the internal relations between them." (Montesquieu, 2000:80)

4. For an introduction to the issue, cf.: Gómez (2004) and Höffe (2005a).

5. 'It is an 'idea' because it is a concept devised starting with a priori regulative principles of reason. More specifically, it is devised in accordance with Kant's theory of natural teleology [...], and in particular in accordance with Kant's conception of the natural teleology of human beings regarded as an animal species." (Wood, 2006:247)

6. For an introduction to Kant's debate on "republicanism", see Almino (1987) and Nour (2003). Nour expresses the most timely understanding among interpreters who see the Kantian republic as comparable, in contemporary terms, to democracy, while Almino is more skeptical about this perspective.

7. A "cosmopolitan constitution" does not discard the idea of a world state or any exclusive transfer of state sovereignty to an international or cosmopolitan entity or realm.

8. See Chapter VII of the UN Charter. In its logical extreme, authors such as Luigi Ferrajoli defend: "the UN Charter highlights, in sum, anticipates the birth of a new international law and the end of the old paradigm - the Westphalian model - [...]. This letter truly equals an international social contract [...] with which international law changes structurally, transforming it from a peace system, based on bilateral treaties inter pares [...], into a truly supranational juridical ordering: no longer a simple pactum associationis [...], but also a pactum subiectionis". (Ferrajoli, 2002:41)

9. This discussion is obviously denser than our interpretive proposal. From a critical perspective, it is pertinent to consider the analysis according to which international law (the UN Charter and peace operations jurisprudence) is merely a sub-product, a normative materialization deriving from war and particularly the interests of World War II victors. In this regard, international law would be at the service of the Security Council's five permanent members. For an introduction to this issue, see Doyle and Sambanis (2006), Hurd (2007), Wet (2004) and MacFarlane and Khong (2006).

10. The passage is in the first footnote of the second section of Perpetual Peace.

11. His political works do not observe the same systematicity (philosophical system) as his writings on other fields, such as the critique of reason.

12. Nour probably refers to paragraph 61, Part II of Groundwork of the Metaphysics of Morals, which states: "such an association of diverse states with the very proposition of preserving peace, which can be called a permanent congress of states [...]. Here, congress should be understood only as a voluntary coalition of different states which can be 


\section{Carlos Enrique Ruiz Ferreira}

dissolved at every moment, and not a union [...] which is based on a constitution and thereby also indissoluble" (Kant, 2007:193).

13. Seminar "Hostipitalité" delivered by Derrida on February 21st, 1996, p. 19. Manuscripts consulted in the archives of Abbaye D'Ardenne, France, in February 2016.

14. In his most exemplary defense: "The right of hospitality is a juridical, not an ethical principle: it focuses on external realms of freedom, not on the adoption of ends. It is not simply an imperfect right that must take a back seat in case of conflict with a perfect one." (Cavallar, 2002:360)

15. Kant states: "The concept of Obligation [...] comprehends that of good intent" (Kant, 2007: 26) and asserts that "it is easy to distinguish whether the action according to obligation was performed by obligation or with selfish intent" (Kant, 2007:27). Stratton Lake synthesizes: "So the duty of beneficence would require not only that we make others' ends our own, but that we do this from duty" (Lake, 2008:112). He specifies: "On this account of the duty of beneficence, we fail to comply with this duty if we make others' ends our own from some other motive, say, from self-interest (indirect egoism), or from inclination." In this respect, specialists (Edmunds, 1871; Höffe, 2005a; Lake, 2000; 2008) note that, for the obligation of virtue to persist, not only the act should be in accordance with the maxims, but the motivation should also be realized without self-interest. In the words of Höffe: "The (metaethical) criterion of morality, the unlimited good-being is fulfilled only where the correct moral is not realized for any other reason than for the fact that it is morally correct, and therefore, where duty itself is required, and as such is fulfilled" (Höffe, 2005a:194).

16 Which contrasts with the Derridian interpretation of Kant.

17 M. Wight inaugurates the category of "revolutionists" in international relations, based above all in Kantian writings. He sees the revolutionary thinking or model as anchored in individuals' morality, which spreads over international relations in the craving for the existence of a "global political community", in contrast with the "realist" or "rationalist" vision, which confers primacy upon the idea of "national interest" - and, within the latter, "international law". Besides classical authors, see also Hurrel (2002) and Oliveira (2002).

18 Höffe - mostly based on Kant's Metaphysical Principles of the Doctrine of Law - says that the philosopher criticizes the idea of an Earth originally without an owner: "The land is not res nullis, but res omnium; the first acquirer does not enter a no man's land, but a common ownership, and therefore does not encounter juridically free objects, but rather a community of all of co-owners" (Höffe, 2005a:249).

19 Brown derives from this analysis the existence of six universal liberties in relation to the laws of hospitality - all of which somehow approached by Kantian works: the freedom to travel; the freedom to leave or migrate (the freedom to exit); the freedom of communication and participation in the public reason (public reason); the freedom of hospitality and from neglect which would result in death; the freedom to participate in trade; and the freedom from falsehood, misrepresentation, extortion and fraudulent contract. 


\section{REFERENCES}

ALMINO, João. (1987), "A paz e a autodeterminação dos povos em Kant". Contexto Internacional, v. 6, a. 3, pp. 37-45.

ANDERSON, Perry. (2005), El estado absolutista (Santos Juliá, Trans.). México: Siglo Veinteuno.

ARON, Raymond. (2002), Paz e guerra entre as nações (Sergio Bath, Trans.). Brasília: UNB/ FUNAG.

ARROYO, Juan Carlos Velasco. (1997), "Ayer y hoy del cosmopolitismo kantiano”. Isegoría - Revista de Filosofia Moral y Política, n. 16, pp. 91-117.

BENHABIB, Seyla. (2006), Another Cosmopolitanism. New York: Oxford University Press.

. (2007), The rights of others - aliens, residents and citizens. Cambridge: Cambridge University Press.

BROWN, Garreth W. (2010), "The Laws of Hospitality, Asylum Seekers and Cosmopolitan Right - A Kantian Response to Jacques Derrida". European Journal of Political Theory, v. 9, n. 3, pp. 308-327.

BULL, Hedley. (1976), "Martin Wight and the Theory of International Relations". British Journal of International Studies, v. 2, n. 2, pp. 101-116.

. (2002), The Anarchical Society - A Study of Order in World Politics. New York: Palgrave.

BYRD, Sharon; HRUSCHKA, Joachim. (2010), Kant's Doctrine of Right. A Commentary. Cambridge: Cambridge University Press.

CAVALLAR, Georg. (1992), Pax Kantiana: systematisch-historische Untersuchung des Entwurfs "Zum ewigen Frieden" (1795) von Immanuel Kant. Wien: Böhlau.

. (2002), The rights of strangers - theories of international hospitality, the global community, and political justice since Vitoria. Aldershot: Ashgate.

CHERNILO, Daniel. (2007), A social theory of the nation-state: the political forms of modernity beyond methodological nationalism. London: Routledge.

COVELL, Chales. (1998), Kant and the Law of Peace: A study in the Philosophy of International Law and International Relations. London: Palgrave Macmillan.

DERRIDA, Jacques. (2004), "O direito à filosofia do ponto de vista cosmopolítico". In: J. Guinsburg (org.), A paz perpétua - um projeto para hoje (J. Guinsburg, Trans.). São Paulo: Perspectiva.

DERRIDA, Jacques; DUFOURMANTELLE, Anne. (2015), De l'hospitalité. Paris: Calmann-Lévy.

DOYLE, Michael W. (2006), "Kant and Liberal Internationalism”. In: P. Kleingeld (ed.), Toward perpetual peace and other writings on politics, peace, and history - Immanuel Kant. New York: Yale University Press.

DOYLE, Michael W.; SAMBANIS, Nicholas. (2006), Making War and Building Peace - United Nations Peace Operations. New Jersey: Princeton University Press.

EDMUNDS, James. (1871), "Kant's Ethics". The Journal of Speculative Philosophy, v. 5, n. 4, pp. 289-307. 


\section{Carlos Enrique Ruiz Ferreira}

FERRAJOLI, Luigi. (2002), A soberania no mundo moderno (Carlo Coccioli; Márcio Lauria Filho, Trans.). São Paulo: Martins Fontes.

GÓMEZ, Enrique Serrano. (2004), La insociable sociabilidad - el lugar y la función del derecho y la política en la filosofía práctica de Kant. Barcelona: Anthropos.

HABERMAS, Jürgen. (1990), "Soberania popular como procedimento - um conceito normativo de espaço público" (Márcio Suzuki, Trans.). Novos Estudos, v. 26.

. (1997) “La idea kantiana de paz perpetua. Desde la distancia histórica de doscientos años." Trad. Juan Carlos Velasco Arroyo. Isegoría - Revista de Filosofia Moral y Política, Madrid, n. 16, pp. 61-90. Available at : <http://isegoria.revistas.csic.es/index.php/isegoria>. Consulted on: Jan 17, 2015.

HÖFFE, Otfried. (2005a), Immanuel Kant (Christian Viktor Hamm; Valerio Rohden, Trans.). São Paulo: Martins Fontes.

. (2005b), A democracia no mundo de hoje (Tito Lívio Cruz Romão, Trans.). São Paulo: Martins Fontes.

HINSLEY, Francis Harry. (1980), Power and the pursuit of peace - theory and practice in the history of relations between states. London: Cambridge University Press.

HURD, Ian. (2007), After Anarchy - Legitimacy and Power in the United Nations Security Council. New Jersey: Princeton University Press.

HURRELL, Andrew. (1990), "Kant and the Kantian Paradigm in International Relations". Review of International Studies, v. 16, n. 3, pp. 183-205.

. (2002), "Forword for the Third Edition". In: H. Bull. The anarchical society - a study of order in world politics. New York: Palgrave.

INTERNATIONAL COMISSION ON INTERVENTION AND STATE SOVEREIGNITY. (2001), The Responsability to Protect. Ottawa: International Development Research Centre.

KANT, Immanuel. (2003a), A Metafísica dos costumes (Edson Bini, Trans.). São Paulo: Edipro.

(2003b), Ideia de uma História Universal de um ponto de vista cosmopolita (Rodrigo Naves; Ricardo Terra, Trans.). São Paulo: Martins Fontes.

. (2004a), A paz perpétua e outros opúsculos. (Artur Mourão, Trans.). Lisboa: Edições 70.

. (2004b), "Sobre a expressão corrente: 'isto pode ser correto na teoria, mas nada vale na prática'". In: I. Kant. A paz perpétua e outros opúsculos (Artur Mourão, Trans.). Lisboa: Edições 70 .

. (2004c), Antropología en sentido pragmático. (José Gaos, Trans.). Madrid: Alianza.

(2007), Fundamentação da metafísica dos costumes. (Paulo Quintela, Trans.). Lisboa: Edições 70 .

KISSINGER, Henry. (1995), La diplomacia. Trad. Mónica Utrilla. México: Fondo de Cultura Económica.

KLEIN, Joel. (2014), "A relação entre ética e direito na filosofía política de Kant". Manuscrito - Revista Internacional de Filosofia, v. 27, n. 1, pp. 165-221. 
KLEINGELD, Pauline. (2006), “Introduction”. In: P. Kleingeld (ed.), Toward perpetual peace and other writings on politics, peace, and history - Immanuel Kant. New York: Yale University Press.

(2013), Kant and Cosmopolitanism - The Philosophical ideal of world citizenship. Cambridge: Cambridge University Press.

LAKE, Philip Stratton. (2000), Kant, duty and moral worth. London: Routledge . (2008), "Being virtuous and the virtues: two aspects of Kant's doctrine of virtue". In: M. Betzler (ed.), Kant's Ethics of Virtue. Berlin: Hubert \& Co.

MACFARLANE, S. Neil; KHONG, Yuen Foong. (2006), Human security and the UN - a critical history. Bloomington: Indiana University Press.

MONTESQUIEU. (2000), O espírito das leis (Pedro Vieira Mota, Trans.). São Paulo: Saraiva.

NOUR, Soraya. (2003), “Os cosmopolitas. Kant e os 'Temas Kantianos' em Relações Internacionais". Contexto Internacional, v. 25, n. 1, pp. 7-46.

. (2004), À Paz Perpétua de Kant. São Paulo: Martins Fontes.

OLIVEIRA, Henrique Altemani de. (2002), "Prefácio". In: M. Wight, (2002), A política do poder. Brasília: UNB/FUNAG.

ORGANIZAÇÃO DAS NACÕES UNIDAS. (2014), Carta das Nações Unidas. Available at: <http:/ / www.onu-brasil.org.br/doc1.php>. Consulted on: Nov 12, 2014.

SCHMITT, Carl. (2002), El nomos de la tierra en el derecho de gentes del "ius publicum europaeum". Granada: Comares.

VITORIA, Franscisco de. (2016), Sobre os índios e sobre o poder civil (Paulo Sérgio de Vasconcellos, Trans.). Brasília: UNB/FUNAG.

WALDRON, Jeremy (2000), "What is Cosmopolitan?". The Journal of Political Philosophy, v. 8, n. 2 , pp. $227-243$.

. (2006), "Cosmopolitan Norms". In: S. Benhabib (ed.), Another Cosmopolitanism. New York: Oxford University Press.

WET, Erika de. (2004), The Chapter VII - Powers of the United Security Council. Portland: Hart Publishing.

WIGHT, Martin. (1987), "An anatomy of International Thought". Review of International Studies, v. 13, n. 3, pp. 221-227.

. (2002), A política do poder. Brasília: UNB/FUNAG.

WILKINS, Burleigh T. (2007), "Kant on International Relations". The Journal of Ethics, v. 11, n. 2, pp. 147-159.

WOOD, Allen W. (2006), "Kant's Philosophy of History”. In: P. Kleingeld (ed.), Toward Perpetual Peace and Other Writings on Politics, Peace, and History - Immanuel Kant. New York: Yale University Press.

WORLD BANK. (2016), Migration and Remittances Factbook 2016. Available at: <http://siteresources.worldbank.org/INTPROSPECTS/Resources/334934-119 9807908806/4549025-1450455807487/Factbookpart1.pdf>. Consulted on: Feb 13, 2018. 


\section{RESUMO}

Investigações Sobre o Cosmopolitismo Kantiano: Evolução da Espécie, Soberania e Hospitalidade

O artigo investiga o cosmopolitismo kantiano a partir das obras do filósofo e de seus principais comentadores. $\mathrm{O}$ artigo elege e destaca três temas centrais e específicos: a evolução da espécie humana, o dilema entre a soberania e o cosmopolitismo e a questão da hospitalidade. Ao iluminar estes temas objetiva suprir uma lacuna da literatura especializada das relações internacionais (em sua interface com a filosofia) na discussão conceitual do cosmopolitismo do filósofo de Könisberg. Sobre a evolução da espécie humana, destaca-se a compreensão do filósofo a partir da "insociável sociabilidade", mecanismo da Natureza que providencia a base elementar para o surgimento do cosmopolitismo e da Paz Perpétua. Sobre o dilema entre a soberania e o cosmopolitismo, cumprirá analisar se existe ou não uma proposta, ou ponderação, por parte do filósofo, que transcende o paradigma da soberania clássica. Por fim, ganha particular relevância a discussão sobre a hospitalidade, que será tratada não apenas em seu aspecto jurídico mas a partir de uma interpretação ética.

Palavras-chave: Immanuel Kant; cosmopolitismo; hospitalidade; soberania; relações internacionais

\section{ABSTRACT \\ Investigations of Kantian Cosmopolitanism: Evolution Of The Species, Sovereignty And Hospitality}

The article investigates Kantian cosmopolitanism, based on the philosopher's works and his main commentators. The study chooses and highlights three central and specific themes: the evolution of the human species, the dilemma between sovereignty and cosmopolitanism, and the issue of hospitality. By casting light on these themes, the article attempts to fill in a gap in specialized literature from the fields of international relations and philosophy. Regarding the evolution of the human species, I emphasize the philosopher's understanding of "unsociable sociability" - a natural mechanism which provides the elementary basis for the advent of cosmopolitanism and perpetual peace. The dilemma between sovereignty and cosmopolitanism leads to the significant analysis of whether Kant has reflected upon or proposed transcending the paradigm of classical sovereignty. Finally, the discussion about hospitality becomes particularly relevant, and is scrutinized according to its juridical and ethical.

Keywords: Immanuel Kant; cosmopolitanism; hospitality; sovereignty; ethics; international relations 


\section{RÉSUMÉ}

Enquêtes sur le Cosmopolitisme Kantien: Évolution De L'espèce, Souveraineté Et Hospitalité

L'article examine le cosmopolitisme kantien, basé sur les travaux du philosophe et de ses principaux commentateurs. L'étude choisit et met en évidence trois thèmes centraux et spécifiques: l'évolution de l'espèce humaine, le dilemme entre souveraineté et cosmopolitisme, et la question de l'hospitalité. En mettant en lumière ces thèmes, l'article tente de combler une lacune dans la littérature spécialisée des domaines des relations internationales et de la philosophie. En ce qui concerne l'évolution de l'espèce humaine, on insiste sur la compréhension du philosophe de la «sociabilité insociable» - un mécanisme naturel qui fournit la base élémentaire de l'avènement du cosmopolitisme et de la paix perpétuelle. Le dilemme entre souveraineté et cosmopolitisme conduit à une analyse significative de la question de savoir si Kant a réfléchi ou proposé de transcender le paradigme de la souveraineté classique. Enfin, la discussion sur l'hospitalité devient particulièrement pertinente et est examinée en fonction de ses aspects juridiques et éthiques.

Mots-clés: Emmanuel Kant; cosmopolitisme; hospitalité; la souveraineté; éthique; relations internationales

\section{RESUMEN}

Investigaciones del Cosmopolitismo Kantiano: Evolución De Las Especies, Soberanía Y Hospitalidad

El artículo investiga el cosmopolitismo kantiano basado en los trabajos del filósofo y sus principales comentaristas. El estudio elige y subraya tres temas específicos y centrales: la evolución de la especie humana, el dilema entre soberanía y cosmopolitismo, y la cuestión de la hospitalidad. Al discutir sobre estos temas, el artículo intenta llenar un vacío en la literatura especializada de los campos de las relaciones internacionales y la filosofía. Al respecto de la evolución de la especie humana, hago énfasis en la comprensión del filósofo de "sociabilidad insociable" - un mecanismo natural que provee bases elementales para el advenimiento del cosmopolitismo y la paz perpetua. El dilema entre soberanía y cosmopolitismo lleva al análisis significativo sobre si Kant ha reflexionado o propuesto trascender el paradigma de la soberanía clásica. Finalmente, la discusión sobre hospitalidad se torna particularmente relevante y se analiza de acuerdo a su componente jurídico y ético.

Palabras clave: Immanuel Kant; cosmopolitismo; hospitalidad; soberanía; ética; relaciones internacionales 